\title{
Climate Change and Agricultural Production in South Africa: Impacts and Adaptation options
}

\author{
Phokele Maponya $^{1} \&$ Sylvester Mpandeli ${ }^{2}$ \\ ${ }^{1}$ Department of Environmental Science, University of South Africa, South Africa \\ ${ }^{2}$ Department of Environmental Affairs, South African Government, South Africa \\ Correspondence: Phokele Maponya, Department of Environmental Science, University of South Africa, Private \\ Bag X6 Florida 1710, South Africa. Tel: 27-114-712-285. E-mail: maponpi@unisa.ac.za
}

$\begin{array}{lr}\text { Received: May 9, } 2012 \quad \text { Accepted: June 11, } 2012 \quad \text { Online Published: August 24, } 2012 \\ \text { doi:10.5539/jas.v4n10p48 } & \text { URL: http://dx.doi.org/10.5539/jas.v4n10p48 }\end{array}$

\begin{abstract}
The primary aim of the paper was to identify the impacts and adaptation options of climate variability and change on agricultural production in Limpopo province. The following objectives were identified: to understand the impacts of climate variability and change on agricultural production in Limpopo province ; to assess the impacts of climate variability and change on agricultural production in Limpopo province and to identify adaptation measures that reduces the impacts of climate variability and change on agricultural production in Limpopo province. A representative sample of 300 farmers aged $16-65+$ years (46 percent males and 54 percent females) participated in the study. The study involved Sekhukhune and Capricorn districts, with 56 percent farmers in Capricorn and 44 percent in Sekhukhune district. The following 11 local municipalities were visited: Elias Motsoaledi, Makhuduthamaga, Fetakgomo, Ephraim Mogale, Tubatse, Lepelle Nkumpi, Blouberg, Aganang, Polokwane, and Molemole. Statistics was used to determine climate variability and change impact on agricultural production. Results indicate that farmers are aware that Limpopo province is getting warmer and drier with increased frequency of droughts, changes in the timing of rains, observed trends of temperature and precipitation. This paper also confirmed that being full time farmer, gender, information on climate change, information received through extension services and adaptation to climate change are some of the important determinants of agricultural production, food scarcity and unemployment. The paper also presented perceived adaptation strategies of selected Limpopo province farmers. Some of their perceived adaptation strategies included: (a) soil management strategies, (b) water management strategies and (c) others like use of subsidies and use of insurance. Other important adaptation options being used by farmers were also discussed in this paper including different adaptation measures against colds, heat, frost, abnormal wind, hail, lack of extension support, nematodes, insecticides, worms, temperature and rainfall. The results of this paper are potentially valuable to the agricultural sector considering the threates that climate change poses across climate sensitive sectors
\end{abstract}

Keywords: climate variability, climate change, agricultural production, Limpopo, South Africa

\section{Introduction}

Climate change directly affects agricultural production, as agriculture sector is inherently sensitive to climate conditions and is one of the most vulnerable sectors to the risks and impact of global climate change (Parry et al., 1999). According to UNEP (2008) "humanity is living beyond its environmental means and running up ecological debts that future generations will be unable to repay as a result of global climate change". Agricultural production remains the main source of livelihood for rural communities in Africa, providing employment to more than 60 percent of the population and contributing about 30 percent of gross domestic product (Nhemachena \& Hassan, 2007). Southern Africa is expected to experience increases in temperature and declining rainfall patterns as well as increased frequency of extreme climate events (such as droughts and floods) as a results of climate change (Nhemachena, 2008).

It was also suggested by World Bank (2010) that South Africa has been getting hotter over the past four decades with average minimum monthly temperature at 138 degrees Celsius and average maximum monthly temperature at 260 degrees Celsius There has also been an increase in the number of warmer days and a decrease in the number of cooler days. Moreover, the country average rainfall, estimated at $450 \mathrm{~mm}$ per year, is well below the average of $860 \mathrm{~mm}$ (World Bank, 2010). In addition, surface and underground water resources are limited. 
Agriculture is expected to be the most affected by these changes because it is highly dependent on climate variables such as temperature, humidity and precipitation (IPCC, 2011).

According to Kgakatsi (2006) climate change can be regarded as the silent enemy likely to affect already high risk and stressed agro ecosystems as the effects of climate change are not immediately visible. Limpopo province is particular vulnerable to climate variability and change as agricultural production depends on climatic conditions and largely on the quality of the rainy season. According to Letsatsi - Duba (2009) climate change in Limpopo province is taking place in the context of other developmental stresses, notably poverty, unemployment and food insecurity which it is feared that it will exceed the limits of adaptation in other parts of the province. It is thus important to develop and implement effective adaptation measures so that climate-related risks and opportunities might support development objectives within provincial policy decision making processes.

The rural community of Limpopo province places great emphasises on growing maize and vegetables. However, adverse climatic conditions will have a bearing on their agricultural production (Mpandeli et al., 2005). This is more likely to affect women more than men as they spend most of their income on food purchases (Makhura, 2001). It could also mean that they now have to spend more time on food gathering processes than before, as less food will be available to families.

The objective of this paper was first to understand the impacts of climate variability and change on agricultural production Limpopo province. Secondly was to assess the impacts of climate variability and change on agricultural production in Limpopo province and thirdly identify adaptation measures that reduce the impacts of climate variability and change on agricultural production in Limpopo province.

\section{Data Collection}

This paper used both quantitative and qualitative designs as questionnaire which included matters relating to climate change and agricultural production was used in the interviews and focus group discussions was conducted after face to face interviews with farmers. A temperature, rainfall and humidity parameters for the past $30-50$ years for two selected districts was obtained from the South African Weather Services. Data on crops yield, tons, production and percent area planted for the past $30-50$ years was obtained from the National Department of Agriculture. Permission was asked from the two district offices to conduct research in their different local municipalities. The following local municipalities were visited: Elias Motsoaledi, Makhuduthamaga, Fetakgomo, Ephraim Mogale, Tubatse, Lepelle Nkumpi, Blouberg, Aganang, Polokwane and Molemole. The survey targeted three hundred farmers in Sekhukhune and Capricorn Districts. The two districts namely Sekhukhune and Capricorn were asked to provide the list of farmers in their municipalities.

\section{Method}

Purposeful sampling technique was used to select three hundred farmers to be interviewed inorder to cover uniformity and homogenous characteristics of farmers. The mixed questionnaire included matters relating to climate change and agricultural production were used in the interviews. Before the interviews start a village meeting was conducted with all community representatives present: chiefs, indunas, local councillors and NGO's. The nature of the research and the contents of the questionnaire were explained to them. Focus group discussion was conducted after face to face interviews with farmers

\subsection{Univariate Analysis Model}

Univariate analysis is able to demonstrate the relationship between dependent and independent variables as stated in the general equation below:

$$
\mathrm{Wi}={ }_{-}+\mathrm{Xi}_{+} \mathrm{i}
$$

\subsection{Multivariate Analysis Model}

The application of multivariate analysis depends on many factors such as nature of variables used, research question, experimental design etc. The equation can be written as follows:

$$
\mathrm{Wi}={ }_{-}+1 \mathrm{INFCi}+\_2 \mathrm{ADCi}+\_3 \mathrm{INFEXi}+\_4 \mathrm{SEXFi}
$$

\section{Results}

Looking at the farming activities, most farmers fall in 50-65+ age group as indicated in Table 1 and this can be as the result of lack of interest in agricultural production from other age categories. This is because young people have identified other opportunities than farming activities in the province, e.g. tendering opportunities with various government departments in the province. It is found from literature that there is variation in age on 
adoption decision. According to Bekele \& Dekele (2003) age had no influence on a farmer's decision to participate in climate change adaptation activities. However, according to Bayard et al. (2007) age is positively related to some climate change adaptation measures. Most farmers in Limpopo province assume that old age is associated with more experience and they expect older farmers to adapt to changes in climate while young farmers are expected to have longer planning horizon and thus to take long term adaptation measures.

Table 1. Age of farmers

\begin{tabular}{lcc}
\hline Variable & Number of Farmers & Percentages \\
\hline $16-24$ & 6 & 2 \\
$25-34$ & 44 & 13 \\
$35-49$ & 61 & 18 \\
$50-64$ & 87 & 26 \\
$65+$ & 102 & 41 \\
\hline Total & $\mathbf{3 0 0}$ & $\mathbf{1 0 0}$ \\
\hline
\end{tabular}

Education and employment are important factors influencing decision to adapt. Most of the farmers in the study have completed some primary education (28.3 percent) while only few farmers have university degree (6 percent) as seen in Table 2. The majority of farmers work fulltime on their farms (97.3 percent) as seen in Table 2. According to Anley et al. (2007) improving education and employment is key to stimulate local participation in various adaptation measures and natural resource management initiatives. It was further emphasised by Maddison (2007) that educated and experienced farmers are expected to have more knowledge and information about climate change and adaptation measures to use in response to climate challenges.

Table 2. Education level of farmers

\begin{tabular}{lcc}
\hline Variable & Number of Farmers & Percentages \\
\hline No Formal Schooling & 20 & 7 \\
Some Primary Education & 63 & 21 \\
Primary Education Completed & 85 & 28.3 \\
Some Secondary Education & 54 & 18 \\
Secondary Education Completed & 33 & 11 \\
Post Secondary Education & 19 & 6.3 \\
Certificates & 8 & 2.7 \\
University Degree & 18 & 6 \\
\hline Total & $\mathbf{3 0 0}$ & $\mathbf{1 0 0}$ \\
\hline
\end{tabular}

Perceptions on long-term temperature are divided into five categories as can be seen in Figure 1. The results indicate that 54.7 percent of farmers perceive that long-term temperatures are increasing. This is true as Jarraud (2011) emphasised that over the last ten years from 2001 to 2010 , global temperatures have averaged $0.46^{\circ} \mathrm{C}$ above the 1961-1990 average, and are the highest ever recorded for a 10-year period since the beginning of instrumental climate records. Only few farmers believed temperature was decreasing, which is an indication that there is change in temperature. On the other hand, the overall perception on long term changes in precipitation is that Limpopo province as indicated in Figure 2 is getting drier and that there are pronounced decreased rainfall altered climatic changes and frequency of droughts (52.7 percent, 15 percent and 8 percent). This shortage of water will have a negative impact on agricultural production.

At least 74 percent of farmers received no support to adapt against changing weather patterns as indicated in Figure 3. Only 5.7 percent farmers received credit; 6.3 percent received insurance and 6.7 percent received subsidies. This is not good at all because lack of credit, insurance and subsidies limit the ability of farmers to get the necessary resources and technology they might need in order to adapt to climate change. According to Kandlinkar and Risbey (2000) since most farmers in Africa are operating under resource limitations: (a) lack of 
credit, (b)subsidies and (c)insurance will accelerate farmers' failure to meet transaction costs necessary to acquire adaptation measures as a result of unexpected weather patterns.

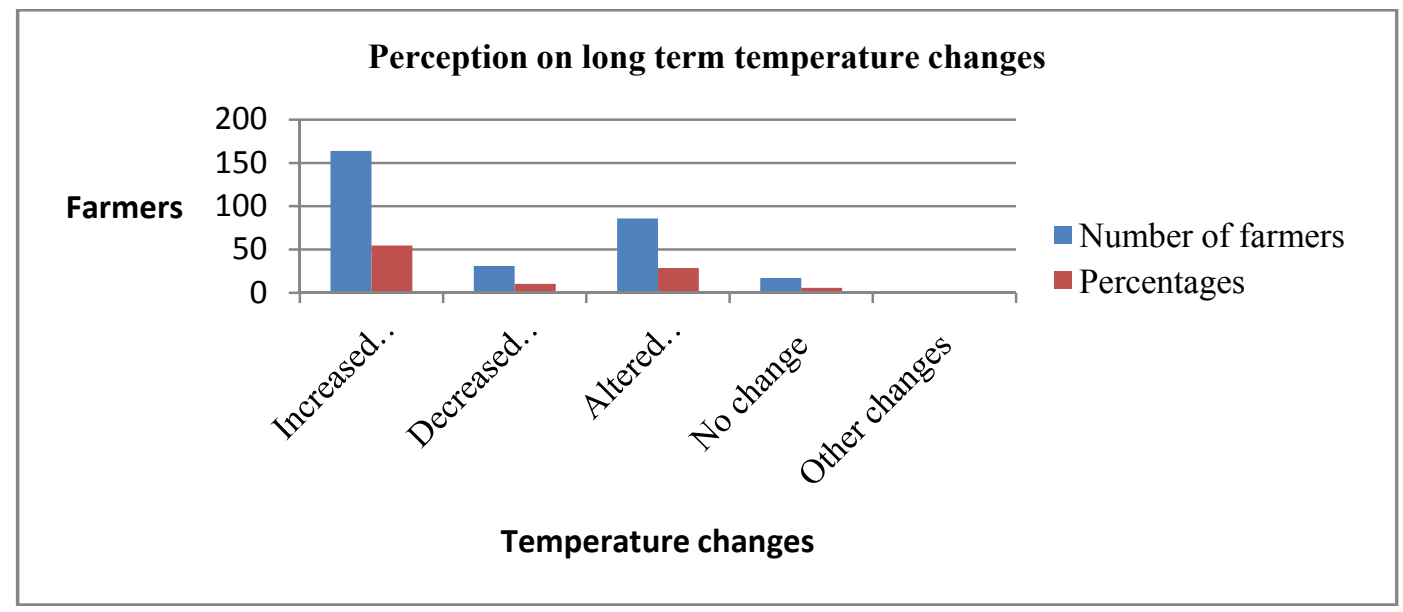

Figure 1. Perception on long term temperature changes

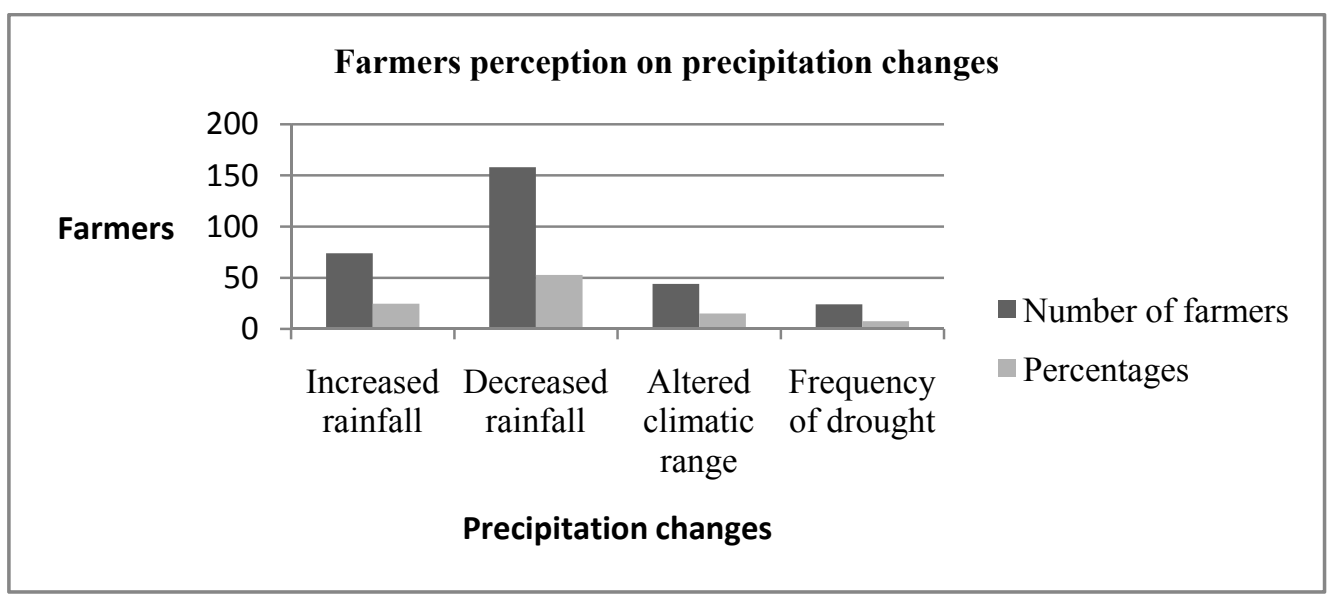

Figure 2. Farmers perception on precipitation changes

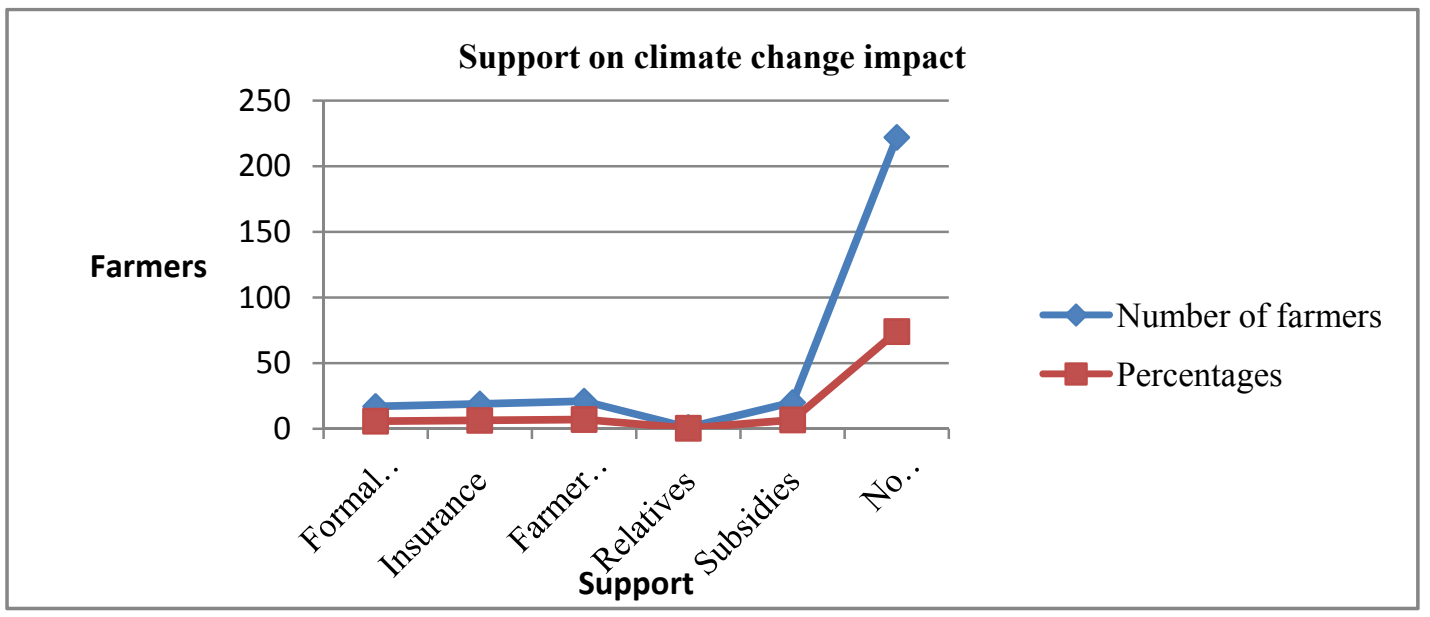

Figure 3. Support on climate change impact 


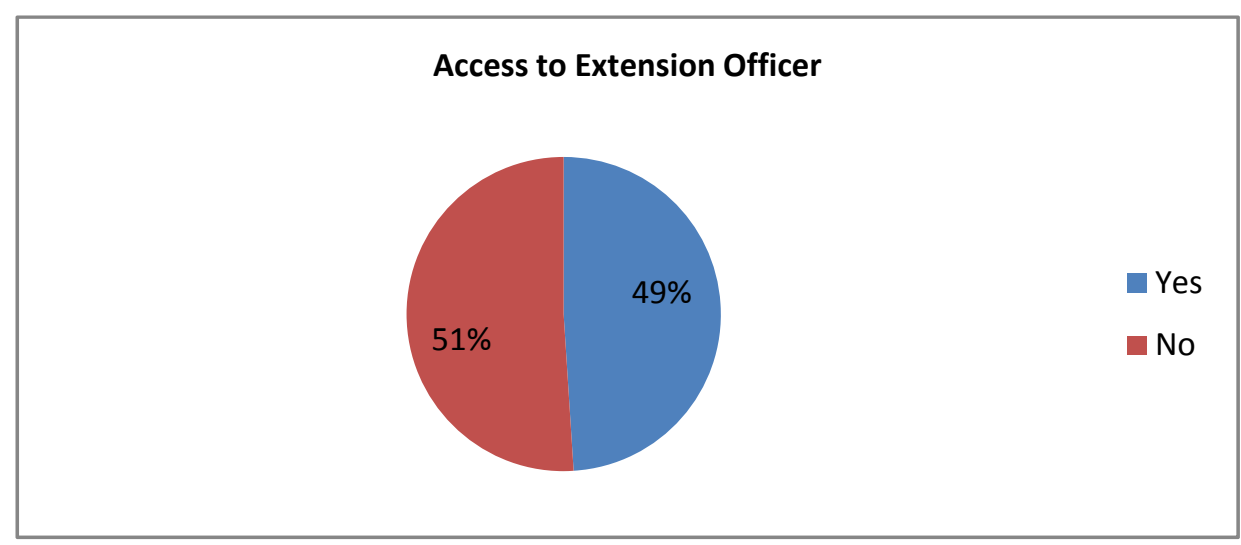

Figure 4. Access to Extension Officer

Extension a service was received by only 49 percent of farmers as indicated in Figure 4 . This is good because extension services enhance the efficiency of making adaptation decisions. This was also recognised by Adesina and Forson (1995) that of many sources of information available to farmers, extension services is the most important for analysing the adaptation decisions. Adesina and Forson (1995) further hypothesized that access to extension services is positively related to adoption of new technologies by exposing farmers to new information and technical skills.

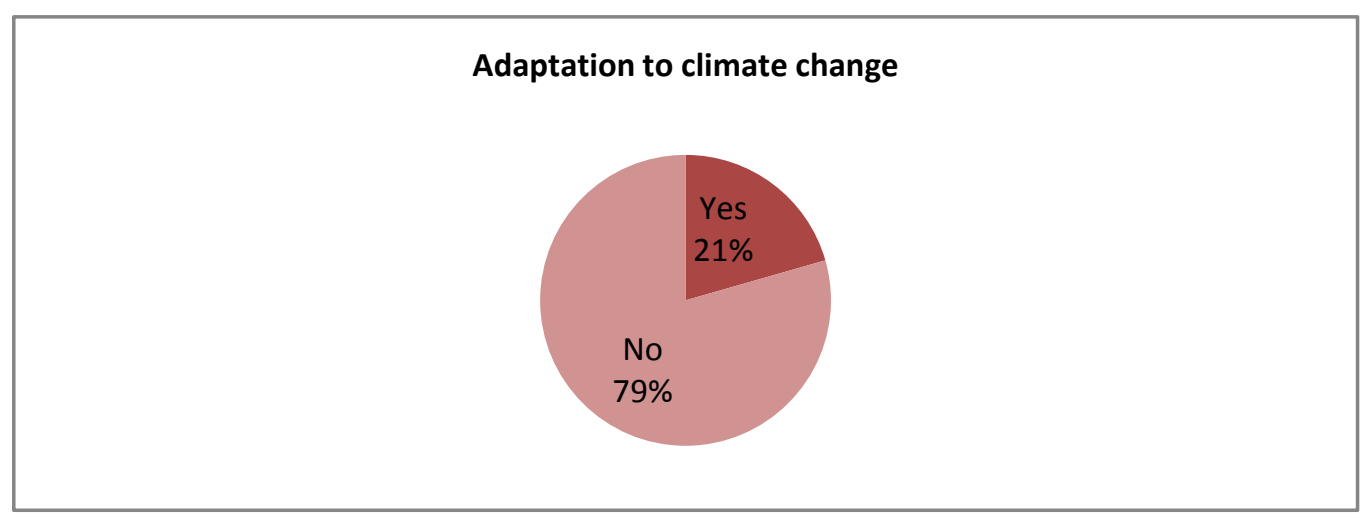

Figure 5. Adaptation to climate change

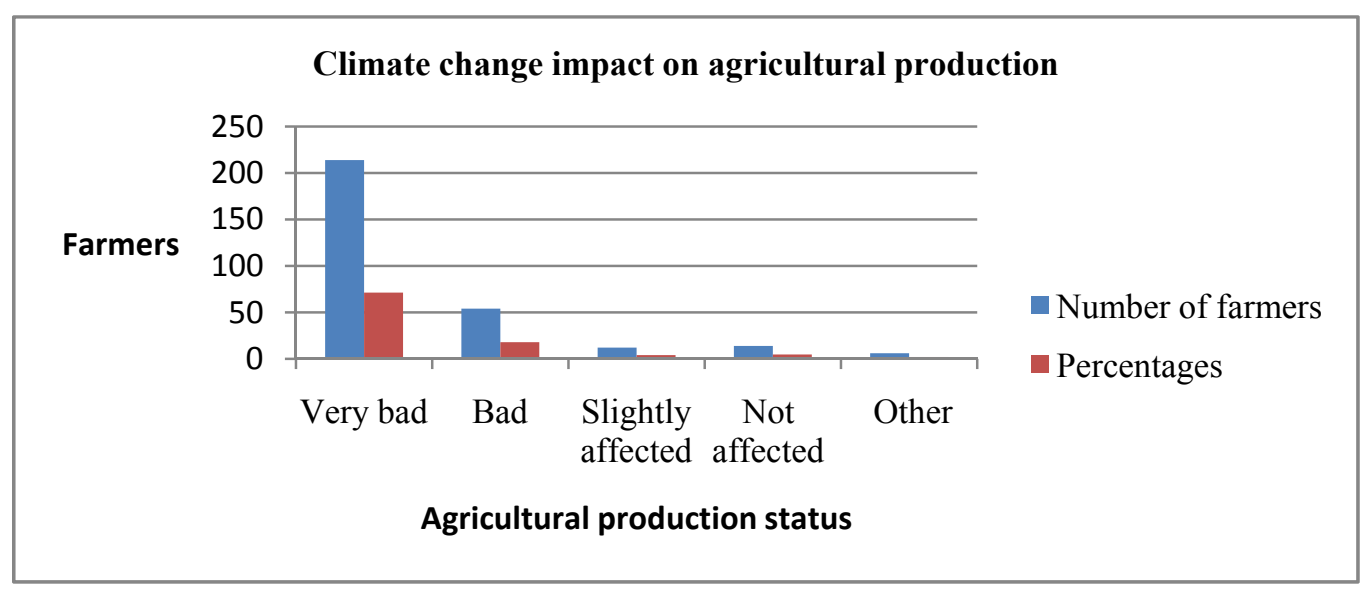

Figure 6. Climate change impact on agricultural production

Based on farmer's response in this paper, it is not surprising to find 79 percent of farmers being unable to adapt as shown in Figure 5. According to Vogel and Reid (2005) the most important thing to adapt against changing 
weather patterns is to strengthen social, economic and environmental resilience of the most vulnerable communities. The climate variability and change situation in Limpopo province has in fact affected farmers agricultural production as evident in Figure 6, whereby 71.3 percent of farmers agreed that climate change has in fact affected their agricultural crop production very bad. This is true as Mpandeli (2005) found that the impact of lower rainfall has negative effects on the agricultural sector and low rainfall will result in (a) decreases in agricultural activities, (b) loss of livestock, (c) shortage of drinking water, (d) low yields and shortage of seeds for subsequent cultivation.

\section{Discussion}

The sample consists of both male and female farmers, with 46 percent male and 54 percent female as seen in Table 3. Various studies have shown that gender is an important variable affecting adoption decisions at the farm level. According to Bayard et al. (2007) female farmers are more likely to adopt natural resource management and conservation practices. It was also emphasised by Burton et al. (1999) that female farmers are indeed important in the choice of agricultural practices to adopt, particularly in regard to conservation or sustainable technology. According to Nhemachena \& Hassan (2007) the possible reason for female to adapt is that in most rural smallholder farming communities, men are more often based in towns, and much of the agricultural work is done by women. Therefore, women have more farming experience and information on various management practices and how to change them, based on available information (Anim, 1999).

Table 3. Summary characteristics of sample in 10 local municipalities

\begin{tabular}{lll}
\hline Variable & Total & Percentage \\
\hline Number of Farmers per District & & \\
Capricorn & 167 & 56 \\
Sekhukhune & 133 & 44 \\
Number of Farmers per Local Municipality & & \\
Aganang & 26 & 8.7 \\
Blouberg & 16 & 5 \\
Polokwane & 31 & 10 \\
Lepelle Nkumpi & 51 & 17 \\
Molemole & 43 & 14.3 \\
Greater Tubatse & 22 & 7 \\
Makhuduthamamga & 20 & 6.7 \\
Fetakgomo & 31 & 10.3 \\
Ephraim Mogale & 52 & 19 \\
Elias Motsoaledi & 8 & 2.3 \\
Sex of Farmers & & \\
Male & 136 & 46 \\
Female & 164 & 54 \\
\hline Total & 300 & 100 \\
\hline
\end{tabular}

But according to Bekele \& Drake (2003) gender has no significant factor in influencing farmers' decision to adopt climate change adaptation measures. They stressed that there is a significant difference in farmer's ability to adapt to climate change due to major differences between them in terms of access to assets, education, credit, technology and input supply.

Table 4 presents farmers perceptions on climate variability and change and 50 percent of farmers prefer crop diversification as one of their adaptation strategy. Crop diversification can also serve as insurance against rainfall variability as different crops are affected differently by climate events (Orindi \& Eriksen, 2005; Adger et al., 2003). As an adaptation to late rain onset some farmers identified the following strategies to adapt as seen in Table 4: use different planting dates (15.7 percent); plant different crops (39 percent); plant different varieties (35 percent). It very clear from the above crop management strategies that majority of farmers did not recognise some of these strategies but there is a tendency that some farmers perceived those crop management strategies which is encouraging. The majority of farmers perceive that soil fertility management may help them against climate variability and change. As seen in Table 4, almost 53 percent of farmers think change use of fertilisers, chemicals and pesticides will improve their adaptation capacity against climate change. According to IPCC (2011) chemicals, fertilisers and pesticides can improve crop yields tremendously but can also be costly to the 
environment. That is why some farmers in Limpopo province are applying organic fertilisers such as those resulting from composting. They believe that by emphasising on organic farming carbon is stored in soils and contribute significantly to the reduction of greenhouse gas emissions. This is true as carbon sequestration in soil has been recognised by Intergovernmental Panel on Climate Change and European Union as one of the possible measures to mitigate greenhouse gases.

Table 4. Descriptive analysis (Perceived farmers adaptation strategies in Limpopo province (\% of respondents)

\begin{tabular}{|c|c|c|}
\hline Variable & Number of Farmers & Percentage \\
\hline \multicolumn{3}{|c|}{ Plant different varieties } \\
\hline Yes & 105 & 35 \\
\hline No & 195 & 65 \\
\hline \multicolumn{3}{|c|}{ Plant different crops } \\
\hline Yes & 118 & 39 \\
\hline No & 182 & 61 \\
\hline \multicolumn{3}{|c|}{ Crop diversification } \\
\hline Yes & 151 & 50 \\
\hline No & 149 & 50 \\
\hline \multicolumn{3}{|c|}{ Use different planting dates } \\
\hline Yes & 47 & 15.7 \\
\hline No & 253 & 84 \\
\hline \multicolumn{3}{|c|}{ Shorten growing period } \\
\hline Yes & 2 & 1 \\
\hline No & 298 & 99 \\
\hline \multicolumn{3}{|c|}{ Move to different site } \\
\hline Yes & 7 & 2 \\
\hline No & 293 & 98 \\
\hline \multicolumn{3}{|c|}{ Change land size } \\
\hline Yes & 5 & 2 \\
\hline No & 295 & 98 \\
\hline \multicolumn{3}{|c|}{ Change crops to livestock } \\
\hline Yes & 2 & 1 \\
\hline No & 298 & 99 \\
\hline \multicolumn{3}{|c|}{$\begin{array}{l}\text { Change from farming to } \\
\text { non farming }\end{array}$} \\
\hline Yes & 10 & 3 \\
\hline No & 290 & 97 \\
\hline \multicolumn{3}{|c|}{ Increase irrigation system } \\
\hline Yes & 198 & 66 \\
\hline No & 102 & 44 \\
\hline \multicolumn{3}{|c|}{ Change use of fertilisers, chemicals and pesticides } \\
\hline Yes & 158 & 53 \\
\hline No & 142 & 47 \\
\hline \multicolumn{3}{|c|}{ Increase water conservation } \\
\hline Yes & 17 & 6 \\
\hline No & 283 & 94 \\
\hline \multicolumn{3}{|c|}{ Soil conservation } \\
\hline Yes & 22 & 7 \\
\hline No & 278 & 93 \\
\hline \multicolumn{3}{|c|}{ Use insurance } \\
\hline Yes & 39 & 13 \\
\hline No & 261 & 87 \\
\hline \multicolumn{3}{|c|}{ Use subsidies } \\
\hline Yes & 43 & 14 \\
\hline No & 257 & 86 \\
\hline Total & 300 & 100 \\
\hline
\end{tabular}


Water management strategies like increased irrigation system was the most perceived strategy of them all. This is not surprising given the socio- economic challenges in Sekhukhune and Capricorn districts. The majority of farmers believe irrigation systems could make them adapt to climate change variability and change. Sixty six percent of farmers prefer improved irrigation systems. The use of irrigation has the potential to improve agricultural productivity through supplementing rainwater during dry spells and lengthening the growing season (Baethgen et al., 2003; Orindi \& Eriksen, 2005). It is important to note that irrigation water is also subject to impacts from climate change. Use of irrigation technologies need to be accompanied by other crop management practices such as use of crops that can use water more efficiently. Important management practices that can be used include: (a) efficient management of irrigation systems, (b) growing crops that require less water, and (c) optimizing of irrigation scheduling and other management techniques that help reduce wastage (Loë et al., 2001). Other perceived strategies were mentioned by few farmers to deal with climate variability and change like (1) Use insurance; (2) Use subsidies; (3) Change land size; (4) Change crops to livestock; (5) Shorten growing period were not popular among most of the farmers.

The results of univariate and multivariate analysis were presented in Tables 5 and 6 . The results indicated that if the odds ratio is $<1$ it means there is a less association among variables and if odds ratio is $>1$ the association is great among variables. All variables are at $95 \%$ confidence interval. Variables that are associated with each other were: employment, sex of farmers, adaptation to climate change, access to information, information received through extension services, agricultural production, food scarcity, food security and unemployment.

Table 5. Univariate analysis of potential determinants of agricultural production

\begin{tabular}{lccc}
\hline Variable & Total & Agric Production (\%) & OR [95\%CI] \\
\hline Sex of farmers & & & \\
Male & 136 & 6.6 & $1.00[0.373-2.403]$ \\
Female & 164 & 6.3 & 1 \\
Employment & & & \\
Working fulltime & 292 & 6.5 & $0.72[0.285-1.141]$ \\
Working part-time & 8 & 0 & 1 \\
Information of climate change & & & \\
Yes & 171 & 2.9 & $4.50[1.585-12.697]$ \\
No & 129 & 11.9 & 1 \\
Adaptation to climate change & & & \\
Yes & 55 & 1.8 & $5.01[1.654-38.383]$ \\
No & 245 & 8.5 & 1 \\
Information received through extension & & & \\
Services & & 4.1 & $2.45[1.585-12.697]$ \\
Yes & 146 & 9.5 & 1 \\
No & 154 & & \\
\hline
\end{tabular}

$\mathrm{OR}=$ Odds ratio; $95 \% \mathrm{CI}=95 \%$ confidence intervals.

According to Table 5 the odds of being affected by climate change are 1.00 percent higher for male farmers than female farmers. This situation is not surprising because it should be acknowledged that women play a vital role in supporting households and communities to adapt to climate change through experience gained in agricultural production. In Africa, for instance women are the primary producers of staple food and they contribute much of labor that will go into coping with climate risks through soil and water conservation (UNDP, 2009). This situation is not different from Limpopo province, where most information was given by female farmers. According to UNDP (2009) across developing countries women's leadership in natural resource management is well recognized. Women for centuries have passed on their skills in water management, forest management and the management of biodiversity, among others. 
The odds of being affected by climate change are 0.72 times less for fulltime farmers than those part-time farmers as indicated in Table 5. This is true because being fulltime farmer increases the ability to take adaptation options. The response of farmers in Limpopo province is in line with the study conducted by Nhemachena \& Hassan (2007) that fulltime farmers will not be affected much by climate change because they are more likely to have more information and knowledge on changes in climatic conditions than part-time farmers. Most of these farmers can also be targeted in promoting adaptation management by government to other farmers who do not have relevant experience and are not yet adapting to climate variability and change.

As indicated in Table 5 the odds of being affected by climate change is 4.50 percent times higher for farmers with information on climate change than those without information on climate change. This situation shows a bleak picture on access to climate information in Limpopo province. Limpopo province farmers should understand that information regarding climate change forecasting, adaptation options and agricultural activities are not easily available on radio and this increases high risks associated with climate variability and change. According to Baethgen et al. (2003) availability of climate and agricultural information helps farmers to make comparative decisions in agricultural production and this allows them to better choose strategies that encourage climate variability, change and adaptation.

Another disturbing response is that of access to extension services by farmers. According to Table 5 the odds of being affected by climate change is 2.46 times higher for farmers that received information through extension services than those who did not receive information through extension services. This situation does not surprise me because some farmers especially resource poor farmers, were complaining that some extension officers do not have relevant qualifications to do the job. Again some extension officers were also complaining that government is not organising relevant training courses that deal with climate variability and change and agricultural production. This is a clear indication that extension officers need to be re-trained in order to provide valuable information to the farmers so that farmers can value them. As Mmbengwa (2009) emphasised that extension services have an important role to play in assisting farmers to acquire new technology, skills, innovation and production advice. So Limpopo farmers and government should priorities extension service because it will significantly increase farmer awareness of changing climatic conditions as well as adaptation measures in agricultural production.

According to Table 5 the odds of being affected by climate change are 5.01 times higher for farmers that can adapt to climate change than those who cannot adapt to climate change. This situation shows that even if some farmers are trying to adapt, the impact of climate change on agricultural production is a reality. Majority of farmers in those districts have agreed that they don't have capacity to adapt but the results also shows that even those who adapt are at risk against changing weather patterns. According to Maddison (2007) situation like this can be addressed by governments like Department of agriculture and forestry, Agricultural research council and South African weather services to raise awareness of the changes in climatic conditions through appropriate communication pathways that are available to farmers such as extension services, farmer groups, input and output dealers, radio and televisions among others. This needs to be accompanied by the various crop and livestock management practices that farmers could take up in response to forecasted changes in climatic conditions such as varying planting dates, using irrigation, or growing crop varieties suitable to the predicted climatic conditions.

Table 6 presents multivariate logistic regression models of agricultural production, unemployment and food scarcity as key outcome variables and information of climate change, adaptation to climate change, information received through extension and services sex of farmers were some of the covariates used. Model I shows that the odds of being affected by climate change are 0.56 less for farmers that receive information of climate change than farmers that do not receive information of climate change. The model also shows that the odds of being affected by climate change are 1.05 higher for farmers who can adapt than farmers that cannot adapt to climate change. It further concludes that the odds of being affected by climate change are 0.54 less for farmers who receive climate change information through extension services than those that do not receive information through extension services. This result showed that through combination of adaptation strategies farmers can be able to adapt against climate variability and change and thus improve agricultural production. Information of climate change is significant in this model at 0.015 . 
Table 6. Multivariate logistic regression model on Agricultural Production; Unemployment and Food scarcity

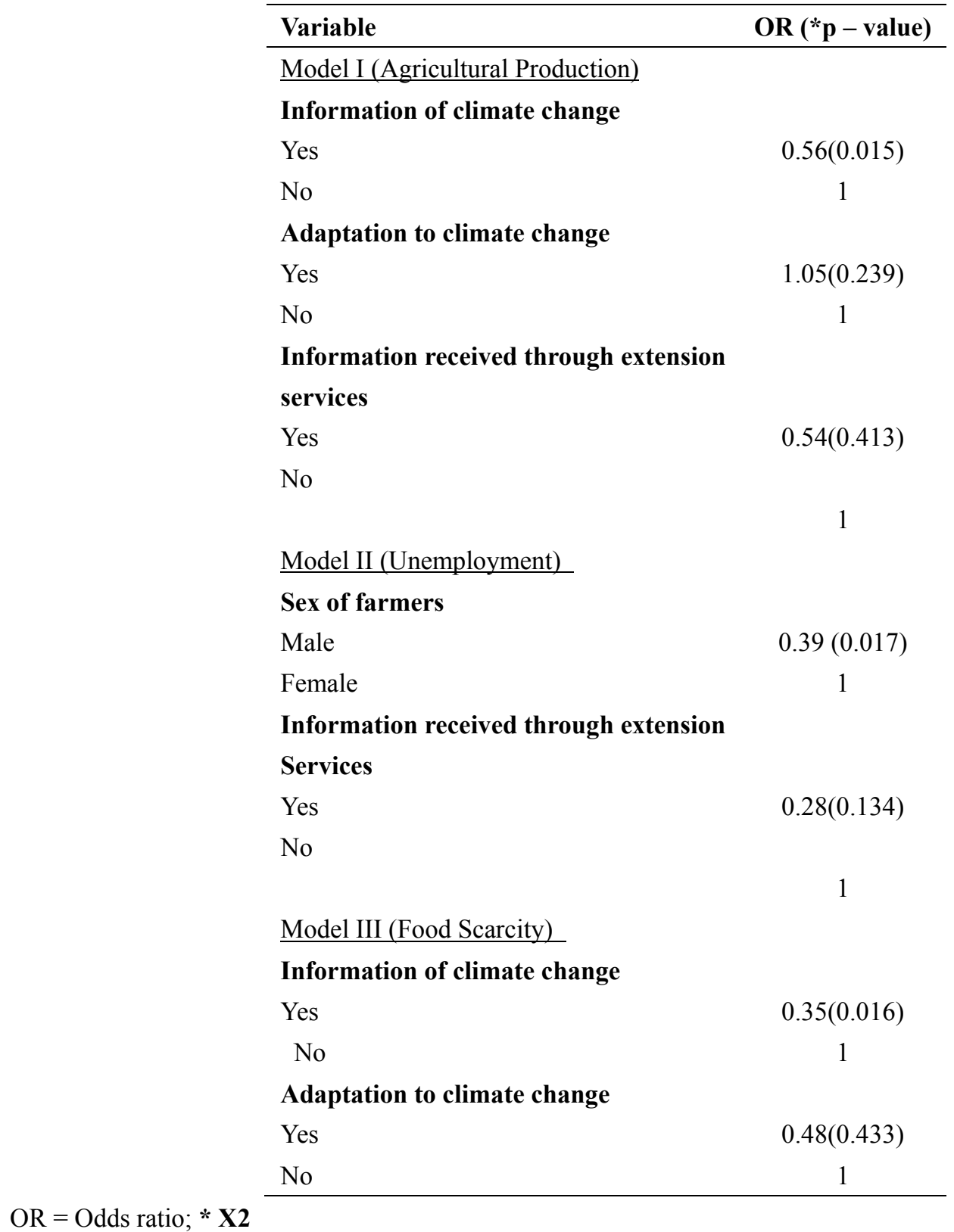

Model II focused on sex of farmers and information received through extension services. The model shows that the odds of being affected by climate change are 0.39 less for male farmers than female farmers. It also shows that the odds of being affected by climate change are 0.28 less for farmers who receive climate change information through extension services than those that do not receive information through extension services. These results showed that by being fulltime farmer with extension services support, farmers can adapt to climate variability and change. This will in turn eradicate unemployment levels. The model concludes by emphasising that sex of farmers is significant at 0.017 .

Model III showed that the odds of being affected by climate change is 0.35 less for famers with information of climate change than farmers that do not have information of climate change. This showed that farmers with climate change information will not experience food scarcity. It further showed that the odds of being affected by climate change are 0.48 less for farmers that can adapt to climate change than those that cannot adapt to climate change. It showed that farmers who adapt to climate change cannot experience food scarcity and further showed the importance of using combination of adaptation measures to adapt against climate variability and 
change. Information of climate change is significant in this model at 0.016 . It can be concluded that information of climate change plays a very important role in agricultural production and food scarcity as seen in Model I and Model III. These models are consistent with Baethgen et al. (2003) who said the availability of climate and agricultural information helps farmers to make comparative decisions in agricultural production and this allows them to better choose strategies that encourage climate variability, change and adaptation.

\section{Summary and Conclusion}

According to IPCC (2011) the scientific community widely agreed that climate variability and change is already a reality. Over the past century, surface temperatures have risen, and associated impacts on physical and biological systems are increasingly being observed. Climate variability and change will bring about gradual shifts such as sea level rise, movement of climatic zones due to increased temperatures, and changes in precipitation patterns. Climate variability and change is also likely to increase the frequency and magnitude of extreme weather events such as droughts, floods and storms and Limpopo Province has already experienced some these weather events especially floods and droughts, example, floods that destroyed crops, infrastructure, affected the harvesting period in 2000 and January 2012 . While there is uncertainty in the projections with regard to the exact magnitude, rate and regional patterns of climate variability and change, its consequences will change the fates of generations to come.

Therefore there is a need for urgent adaptation strategies in the agricultural sector is required to the changes in climate especially in Africa where millions of people depend on it for survival. According to UNFCCC (2008) Africa will be hit hardest by climate change as larger areas could be stricken by yield decreases of over 50 percent by the year 2020 as results of increasingly hotter and drier climate. This will threaten food security and people livelihoods in most parts of Africa. It is against this background that means have to be found to adapt to climate variability and change and therefore essential for development partners to deliver on their commitments to support African countries to adapt to the unavoidable impact of climate change which includes scaling up efforts in order to (a) improve and increase access to climate data; (b) investment and transfer of technologies for adaptation in key sectors; (c) developing and implementing best practice guidelines for screening and assessing climate change risk in their development projects and programs in climate sensitive sectors; (d) mainstreaming climate factors into development planning and implementation; (e) providing significant additional investment in disaster prevention. The summary and conclusions are presented under the following headings: (a) Information of climate change, (b) Adaptation to climate change, (c) Information received through extension services,(d) Drought, (e)Indigenous coping strategies and (f) Crop diversification.

(a) Information of climate change

Farmers need adequate knowledge about the importance of climate change in order for these farmers to be able to adapt effectively. So, transfer of climate knowledge to support vulnerability and adaptation measures are advocated in this regard. To accomplish these farmers should use different information sources like the media both printing and the electronic, research institutions such as the Agricultural Research Council, agricultural extension services and civil societies like NGOs for the dissemination of the climate change, climate advisory information across various farmers in the province.

(b) Adaptation to climate change

The extreme weather patterns caused by climate variability and change in Limpopo province have impacted the farming communities severely for the past several years. The majority of these farmers have limited adaptive capacity, finance and technology to respond towards climate change challenges. These farming communities must use identified adaptation measures in this study and use the resources available to them to tackle climate variability and change.

(c) Information received through extension services

The role of agricultural extension officers should be further explained to the farming communities in Limpopo province. This must include Agricultural extension officers role in encouraging farmers to adopt new technologies, improved methods of farming, using a variety of methods to reach farmers i.e. organizing study groups for farmers, farmer days, demonstrations, lectures and literature, as well as informing the media about farmers challenges.

(d) Drought

Drought is a recurring problem in Limpopo province. According to Mpandeli (2005) in times of drought, different coping strategies should be gathered, understood and shared amongst a range of end users e.g. either by the National agro meteorological committee, research institutions such as Agricultural Research Council and the 
South African Weather Service. Limpopo farmers should also be encouraged to use drought-resistant cultivars during drought periods.

(e) Indigenous coping strategies

Indigenous coping strategies should play an integral role in building climate resilience. Indigenous coping strategies must not only be sought and recognized, but also integrated with conventional science if farmers are planning to tackle climate change challenges in the agricultural sector

\section{(f) Crop diversification}

Farmers should be encouraged and enabled to use crop diversification as adaptation coping strategy. This is a common practice to find many crop species on the same piece of land to guard against crop failure in times of adverse climatic conditions.

The results of this paper are potentially valuable to the agricultural sector considering the international and local debate and interest in order to counter act the impact of both the climate variability and change.

\section{References}

Adesina, A. A., \& Forson, J. B. (1995). Farmers' perceptions and adoption of new agricultural technology: Evidence from analysis in Burkina Faso and Guinea, West Africa. Agricultural Economics, 13, 1-9.

Adger, W. N., Huq, S., Brown, K, Conway, D., \& Hulme, M. (2003). Adaptation to climate change in the developing world. Progress in Development Studies, 3, 179-195.

Anim, F. D. K. (1999). A note on the adoption of soil conservation measures in the Northern Province of South Africa, Journal of Agricultural Economics, 50, 336-345

Anley, Y., Bogale, A., \& Haile-Gabrile, A. (2007). Adoption decision and use intensity of soil and water conservation measures by smallholder subsistence farmers in Dedo district, western Ethiopia. Land degradation and development, 18, 289-302.

Baethgen, W. E., Meinke, H., \& Gimene, A. (2003). Adaptation of agricultural production systems to climate variability and climate change: lessons learned and proposed research approach. Paper presented at Climate Adaptation.net conference "Insights and Tools for Adaptation: Learning from Climate Variability," 18-20 November, 2003, Washington.

Bayard, B., Jolly, C. M., \& Shannon, D. A. (2007). The economics of adoption and management of alley cropping in Haiti. Journal of Environmental Management, 84, 62-70.

Bekele, W., \& Drake, L. (2003). Soil and water conservation decision behaviour of subsistence farmers in the Eastern Highlands of Ethiopia: a case study of the Hunde-Lafto area. Ecological Economics, 46, 437-451.

Burton, M., Rigby, D., \& Young, T. (1999). Analysis of the determinants of adoption of organic horticultural techniques in the UK. Journal of Agricultural Economics, 50, 47- 63.

IPCC (Intergovernmental Panel on Climate Change). (2011). Managing the risks of extreme events and disasters to advance climate change adaptation, A special report on working group I and working group II of the intergovernmental panel on climate change. http://www.ipcc.ch/ipccreports/ar4-syr.htm [accessed: 11 January 2012].

Jarraud, M. (2011). World meteorological organization: 2010 equals' record for world hottest year and the data confirm the earth significant long term warming trend. WMO secretary general report.

Kandlinkar, M., \& Risbey, J. (2000). Agricultural impacts of climate change: if adaptation is the answer, what is the question? Climatic Change, 45, 529-539.

Kgakatsi, I. (2006). Climate change and the DoA: Yesterday, today and tomorrow, Proc. agricultural sector in climate change workshop. Feb. 2006, Pretoria, South Africa.

Letsatsi Duba, D. (2009). Drought issues in Limpopo province, MEC of agriculture, Polokwane, Limpopo province.

Loë de, R., Kreutzwiser, R., \& Moraru, L. (2001). Adaptation options for the near term: climate change and the Canadian water sector. Global Environmental Change, 11, 231-245.

Maddison, D. (2007). The Perception of and Adaptation to Climate Change in Africa. Policy Research Working Paper 4305. World Bank, Washington DC. 
Makhura, M. T. (2001). Overcoming transaction costs barriers to market participation of smallholder farmers in Limpopo province of South Africa, Published PhD Thesis, University of Pretoria.

Mmbengwa, V. M. (2009). Capacity buiding strategies for sustainable farming SMMEs in South Africa, PhD (Agricultural Economics) Dissertation, University of the free state, Bloemfontein.

Mpandeli, N. S. (2005). Coping with climate variability in Limpopo Province. Sustainable Rural Livelihoods Technical Report.

Mpandeli, S., Simalenga, T., Siambi, M., Ramgondo, R., Mailula, N., \& Liphadzi, K. (2005). Constraints and challenges to agricultural development in Limpopo province, South Africa.

Nhemachena, C., \& Hassan, H. (2007). Micro-level analysis of farmers' adaptation to climate change in Southern Africa. IFPRI Discussion Paper No. 00714. International Food Policy Research Institute, Washington, D. C.

Nhemachena, C. (2008). Agriculture and future climate dynamics in Africa: Impacts and adaptation options. PhD Thesis. Department of Agricultural economics, extension and rural development. University of Pretoria.

Orindi, V. A., \& Eriksen, S. (2005). Mainstreaming adaptation to climate change in the development process in Uganda. Ecopolicy Series 15. Nairobi, Kenya: African Centre for Technology Studies (ACTS).

Parry, M. L., Fischer, C., Livermore, M., Rosenzweig, C., \& Iglesias, A. (1999). Climate change and world food security: a new assessment. Global environmental change, 9, S51-S67.

UNDP (United Nations Development Programme). (2009). Women role in poverty reduction strategies in Africa United Nations Mozambique: UNDP.

UNEP (United Nations Development Program). (2008). Human Development Report. http://www.undp.org.za[Accessed 05 June 2009].

UNFCCC (United Nations Framework Convention on Climate Change). (2008). Challenges and Opportunities for Mitigation and Adaptation in the Agricultural Sector: Technical Paper, http://unfccc/resource/docs/2008/tp/08.pdf. [Accessed: 15 September 2010].

Vogel, C., \& Reid, P. (2005). Vulnerability, adaptive capacity, coping and adaptation: A conceptual framework. In Climate Change and Water Resources in Southern Africa, Studies on Scenarios, Impacts, Vulnerabilities and Adaptation. Pp 352-358. Schulze RE (ed.). Water Research Commission, Pretoria, South Africa Report $1430 / 1 / 05$.

World Bank. (2010). Africa rainfall and temperature evaluation system (ARTES). World Bank, Washington DC. 